\title{
STANDARDIZATION IN SERVICES: ASSESSING THE IMPACT ON CUSTOMER SATISFACTION
}

\author{
Oksana Koval, Stephen Nabareseh, Felicita Chromjaková
}

\section{Introduction}

The service organizations develop complex service offerings and procedures to cater to the changing customers' requirements. The increased complexity of the service processes halts effectiveness of the operations and may lead to the lower firm competitiveness over time (Schäfermeyer, Rosenkranz, \& Holten, 2012). The complexity of service operations induces long waiting times for customers and high non-value added costs for the companies (George, 2003), and the diversity of the service offerings challenges effectiveness of the processes (Carlborg, Kindström, \& Kowalkowski, 2013; Silvestro \& Lustrato, 2015). Due to the direct customer participation in the service production, customer has power to significantly impact and distort service operations (Zomerdijk \& de Vries, 2007). Thus, to tackle the issue of redundancy and improve performance, companies make determined efforts to standardize their operations.

The standardization boosts enterprise performance through cost, time reduction and quality improvement (Davenport, 2005; Münstermann, Eckhardt, \& Weitzel, 2010). The unification of the business processes leads to the improved control and collaboration between departments (Wuellenweber, Koenig, Beimborn, \& Weitzel, 2009). The drive for continuous improvement is now prominent in the services segment, and the process standardization is critical to ensure effectiveness of improvement efforts (Anderson, Rungtusanatham, Schroeder, \& Devaraj, 1995; Berger, 1997). The goal of standardization and continuous improvement is to achieve higher customer satisfaction in the light of the changing customer preferences, while delivering performance benefits (Anderson, Fornell, \& Rust, 1997; Deming, 1993; Imai, 1986; Liker \& Morgan, 2006). However, excessive standardization may have negative impact on customer satisfaction, since standard operations may not tailor to the needs of the varied customer base (Babbar, 1992; Hsiao, Chen, Chang, \& Chiu, 2016; Lillrank, Shani, \& Lindberg, 2001). Thus, in the face of the growing customization trend, companies face the conflicting trade-off to meet customer demands and deliver performance improvements (Silvestro \& Lustrato, 2015).

Our analysis of the literature reveals the scarcity of studies on the impact of standardization on customer satisfaction, yet less in services. The study of Münstermann, von Stetten, Laumer and Eckhardt (2010) on standardization of human resource processes provides for a rare exception. The present study contributes to the scant field of knowledge of standardization application in services, since the previous research has mainly focused on healthcare, telecommunication and manufacturing industries. The majority of the studies on standardization assesses the saving gains, often overlooking the importance of customer satisfaction, even though customer satisfaction is linked to a higher customer retention and improved revenue (Rust \& Chung, 2006; Tyagi \& Gupta, 2013). The existing accounts also fail to consider standardization within the wider organizational improvement process that often takes place simultaneously.

Standardization of the operations involves significant costs due to the investment in the design of the new processes and employee training (Wang, Wang, Ma, \& Qiu, 2010). At the initial stage of standardization, the required investmentmayoutweighthe benefits associated with the higher process reliability and a minimal customer satisfaction improvement. However, effective implementation of the standardized processes will eventually bring in economies of scale and tremendous improvement of the service quality (Wang et al., 2010). 
Despite the importance of standardization for modern businesses, the conditions fostering effectiveness of standardization remain largely understudied. The previous research has focused on identifying what level of process variety as opposed to standardization should be kept, in order to meet customer requirements (Afflerbach, Bolsinger, \& Röglinger, 2016). In their research, Schäfermeyer et al. (2012) find that complexity of the processes significantly hinders business process standardization. Romero et al. (2015) builds upon contingency theory and identifies three groups of the factors that impact standardization: external (differences in culture and legislation), internal (organizational structure and level of company dispersion) as well as immediate (managerial preferences).

Standardization is inherent to continuous improvement; yet, there is a dearth, if not absence, of the research regarding how factors that impact continuous improvement, influence standardization and operational performance of the firm. To resolve this discrepancy in our research we provide an alternative approach to understanding the factors influencing relationship between standardization and customer satisfaction through the prism of continuous improvement; thus, we argue that factors that are proven to influence continuous improvement will also foster standardization in the organizations. The goal of the research is to assess the impact of continuous improvement practices on the standardization - customer satisfaction relationship in the context of the services firms. The growing dependence of the global economy on the services sector and a lack of the research on the service companies provide a compelling case for the study.

\section{Literature Review}

\subsection{Standardization and Continuous Improvement}

Standardization of the operations enables organizations to remove non-value added work through reduction of complexity and excessive redundancy. The organizations employ process standardization to achieve uniformity and transparency of the operations across value chain (Wuellenweber et al., 2009). Shaw, Holland, Kawalek, Snowdon and Warboys (2007) consider standardization as an organizational effort to bring operations to a single standard business process.
Standardized operations reduce variance associated with each task, minimize ambiguity, and help employees avoid costly mistakes (Crosby, 1979; Gilson, Mathieu, Shalley, \& Ruddy, 2005). The unification of the processes ensures high quality of the delivered services. However, Taubitz (2014) found that excessive standardization can lead to the errors and violation of occupational safety.

Shaw et al. (2007) define standardization as a part of the "meta" process of continuous improvement in the organization. The process standardization is embedded within the concept of continuous improvement, ensuring communication and information flow between the individuals and teams, involved in the improvement projects, through unification of the best practices and communication tools (Matson \& Stauffer, 2009; Nakamura, 1993). In the Six Sigma DMAIC cycle (Define-MeasureAnalyze-Improve Control) standardization is fundamental to the Control stage, where the newly established refined processes are documented, employees are trained and the monitoring plans are established; thus, making the new process an accepted standard (Boon Sin, Zailani, Iranmanesh, \& Ramayah, 2015; Pyzdek \& Keller, 2009).

Continuous Improvement $(\mathrm{Cl})$ is an umbrella concept tying together improvement methodologies such as Total Quality Management, Lean and Six Sigma into a comprehensive improvement approach, benefiting from the complementary nature of the methodologies (Berger, 1997). Continuous improvement is an ongoing refinement of the standards established within the organization and standardized processes are the prerequisite for the further changes (Berger, 1997; Nakamura, 1993). As a testimony to this statement, Berger (1997) provides an example of the PDCA (Plan-DoCheck-Act) loop of the Lean methodology, where every improvement efforts leads to the establishment of the new standard operations that are continuously improved through the application of PDCA.

\subsection{Relationship between Services Standardization and Customer Satisfaction}

Customer satisfaction (CS) is typically viewed as an extent to which perceived service performance corresponds to the prior customer expectations (Anderson 
et al., 1997). The quality of the provided service, as perceived by the customer, has an intricate impact on customer satisfaction, and is dependent on the homogeneity of the service quality (Parasuraman, Zeithaml, \& Berry, 1998; Romero et al., 2015; Wang et al., 2010). The objective of the service operations standardization is to satisfy as many customers as possible, while accommodating only a limited number of customer needs, which is akin to the mass production of goods (Simonson \& Nowlis, 2000). Gilson et al. (2005) suggest that customers may perceive employees, trained to perform operations based on the set of standards, as more knowledgeable, which, in turn, should lead to the higher customerperceived quality of the service. Thus, due to the high level of interaction with the customers during the service production, standardization of processes could be especially relevant the service employees.

The standardization of processes have led to the emergence of the term "McDonaldization" in the service industries (Ritzer, 2011). The standardized processes provide an advantage of predictability and consistency of the service standard; thus, delivering the same high level of service quality and customer satisfaction during every interaction with the organization (Ding \& Keh, 2016; Hsieh \& Hsieh, 2001). The technological advancements and invention of self-service technologies has led to a higher level of service consistency, especially in travel, hospitality, banking and retail industries (Levitt, 1976). The researchers have demonstrated that customer satisfaction depends on the quality of the service; however, little research has been done to address the question of how standardization of the service affects customer satisfaction.

There is a disagreement among scholars regarding the nature of the relationship between customer satisfaction and standardization. Operations research and production management literature suggests that this relationship is positive (Crosby, 1979; Deming, 1993; Juran, 1988). In their research Münstermann, Eckhardt, et al. (2010) found that standardization of the hiring process delivered $30 \%$ cost reduction. In economics literature, however, it is maintained that an increased customer focus leads to the growth of the production costs, lower efficiency and productivity (Anderson et al., 1997; Hart, 1995;
Wang et al., 2010). The researchers Chiang and $\mathrm{Wu}$ (2014) postulate that standardization of the service operations leads to the increase of customer orientation among employees. There is also evidence of the positive impact of process standardization on job satisfaction (Chiang \& Wu, 2014; Hsieh \& Hsieh, 2001). However, Rust, Jeffrey, Jianmin and Zahorik (1999) assert that excessive customization can be harmful to the retention of customers. Gilson et al. (2005) have similar findings: teams with the standard processes achieve higher customer satisfaction, however, excessive standardization may reduce employee creativity and problem solving skills, thus, resulting in reduction of customer satisfaction. Building on the previous research we hypothesize that standardization positively influences customer satisfaction:

Hypothesis 1 (H1): Standardization has a positive impact on customer satisfaction.

\subsection{Factors Influencing Effectiveness of Standardization and Measurement Item}

The standardization-customer satisfaction relationship is embedded within the wider organizational context, and, consequently, is affected by the heterogeneous internal and external factors (Duncan, 1972). In our research we follow previous studies linking standardization to customer satisfaction. We consider standardization a part of an ongoing continuous improvement process within the organization. With this assumption in mind, we build further hypotheses and propose the following statements regarding standardization: 1) standardization is inherent to continuous improvement; 2) continuous improvement has a positive impact on customer satisfaction, thus, standardization also positively impacts customer satisfaction; 3) the relationship between standardization and customer satisfaction can be impacted by the factors, that are proven to foster continuous improvement.

To reflect the complex relationship between standardization and customer satisfaction, we introduce multiple mediators, following Shah and Goldstein (2006). There is a scant research regarding factors that influence standardization in the firms. Since standardization is one of the key elements of $\mathrm{Cl}$, in our research we argue that the factors, influencing $\mathrm{Cl}$, also have impact on standardization. We draw further 
hypotheses based on the notion of relatedness of standardization to $\mathrm{Cl}$. The survey items were contextualized from prior research and modified for application in the services industry. To operationalize the constructs, the suitable measurements were adapted from the research literature (see Appendix A). In line with the literature review we asked research participants to evaluate influence of Standardization on improvement of customer satisfaction on the 1-5 Liker-type scale, where 1 is for Strongly Disagree and 5 for Strongly Agree. We consider customer satisfaction as the major indicators of operational performance based on Imai (1986), Deming (1993); Bessant and Francis (1999); Anand et al. (2009). We adapt the Standardization measure from Deming (1993), Kim, Kumar and Kumar (2012) as well as Liker (2006). Fig. 1 provides the model of the hypothesized relationships.

\section{Employee Rewards and Recognition}

Rewards and recognition aid in reducing employee resistance towards the changes, associated with the process standardization and improvement projects. When not rewarded appropriately, employees may sabotage the improvement initiative (Oláh, Szolnok, Nagy, Lengyel, \& Popp, 2017; Tronvoll, Brown, Gremler, \& Edvardsson, 2011). At the same time, organizations that have designed employee rewards and recognition systems that ensure high level of employee involvement and participation, report better results from process improvement (Habtoor, 2016; Yang, Lee, \& Cheng, 2014). In our research, we argue that employee rewards and recognition facilitate process standardization in the company. Identification of the process standardization opportunities requires efforts on the side of employees, and appropriate rewards system will drive employee motivation towards higher standardization.

Hypothesis 2 (H2): Effective recognition and reward system reinforces the positive relationship between standardization and customer satisfaction.

\section{Quality-Oriented Culture}

The quality-oriented culture engages employees at every level by promoting shared value of customer focus. Consequently, in an attempt to deliver the service or product of consistently high quality, organizations tend to standardize their processes. Researchers acknowledge the fundamental role of the quality-oriented culture for effectiveness of improvement efforts (Calvo-Mora, Picón, Ruiz, \& Cauzo, 2013; Habtoor, 2016). Quality culture directly influences the level of employee involvement in process improvement and standardization (Tsironis \& Psychogios, 2016). Sophisticated quality culture serves as an integrating tool for organizations, and helps them to overcome implementation barriers (Detert, Schroeder, \& Mauriel, 2000; Dow, Samson, \& Ford, 1999; Prajogo \& Brown, 2006). We conceptualize this mediator from Detert et al. (2000); Bortolotti et al. (2015); Jayanth and Xu (2016).

Hypothesis 3 (H3): Quality-oriented culture positively mediates the relationship between standardization and customer satisfaction.

\section{Management Commitment}

The management of the organization should be the driving force behind improvement initiative (Powell, 1995; Bessant \& Francis, 1999; Bortolotti et al., 2015; Habtoor, 2016). Leadership can demonstrate its commitment to the improvement and standardization by providing resources at the operational level and defining strategic goals that incorporate process improvement at the organizational level (Haikonen, Savolainen, \& Järvinen, 2004). Management commitment to process improvement facilitates trust in leadership among employees, which further fosters employee autonomy and proactive process improvement (Anand et al., 2009; Chromjaková, 2016). Process improvement should involve employees from the shop floor to the top-level management in order to be effective (Liker \& Morgan, 2006). Leadership of the organizations should exemplify the core continuous improvement values and ensure that the resources, required for process improvements and standardization are allocated; thus demonstrating commitment to the improvement effort (Imai, 1986; Kaye \& Anderson, 1999). Accordingly, we hypothesize that high management commitment will lead to the high levels of process standardization.

Hypothesis 4 (H4): Management commitment reinforces the positive relationship between standardization and customer satisfaction.

\section{Training and Development of Employees}

Training of employees is a complex factor that can be viewed as an education on the 
job-related skills or on the improvement method. In the proposed research, we take the latter stance and assess impact of the training on improvement methodology on the customer satisfaction and standardization. The previous studies largely focus on the jobrelated, rather than on specific improvement methodology training (Pont, Furlan, \& Vinelli, 2009; Zeng, Phan, \& Matsui, 2013) and there is a general lack of the studies on the impact of the improvement methodology training on the operational performance. However, Pollitt (2013) observed the foundational role of training for the effectiveness of improvement effort in the organization. Thus, we hypothesize that training in improvement techniques will facilitate standardization in the company. We argue that appropriate training equips employees with the set of skills to identify standardization opportunities:

Hypothesis 5(H5): Training and development of employees have a positive impact on the standardization-customer satisfaction relationship.

\section{Goal Setting and Project Management}

The proper selection and coordination of improvement projects corresponding to the strategic goals can lead to an improved operational effectiveness (Choo, Linderman, \& Schroeder, 2007; Kaynak, 2003; Powell, 1995). The developed system of the improvement projects, aligned with the strategic goals of the company, are cardinal to sustainability of the improvement initiative beyond the initial roll-out (Anand et al., 2009; Calvo-Mora et al., 2013). For a long-term effectiveness of improvement initiative, the organization needs to rigorously select projects that meet customers' needs (Jääskeläinen, Laihonen, \& Lönnqvist, 2014); otherwise, failure to adopt a customer-focused approach may lead to deterioration of organizational performance. Organizations that identify projects based on their importance to the strategic priorities are more integrated and able to overcome unnecessary complexity (Galeazzo, Furlan, \& Vinelli, 2016). Researchers emphasize the necessity of a unified coordination and goal setting of improvement initiatives and ascertain positive impact of project management on effectiveness of the improvement initiative (Gonzalez \& Martins, 2016). Thus, we argue that the organizations exercising goal setting and project management for improvement initiative would benefit from a higher level of process standardization. We adapt the mediator Goal Setting and Project Management from Galeazzo et al. (2016), Kaynak (2003), Sabella, Kashou and Omran (2014).

Hypothesis 6 (H6): Goal setting and project management reinforce the positive relationship between standardization and customer satisfaction.

\section{Methodology - Data Collection and Sample}

The data was collected through the survey instrument in four countries: the Czech Republic, Poland, Slovak Republic and Hungary that form a Visegrad Four (V4) group. We used databases from the national investment and development agencies to identify initial contacts in the service companies (see ABSL, 2016; Czechlnvest, 2015; HIPA, 2015; PITA, 2015; SARIO, 2015), and further used snowballing technique as well as information available online to reach wider research sample (Edmondson \& McManus, 2007). To gather data from the service firms with sufficient number of managers, we aimed at selecting companies with more than 100 employees. Experience in continuous improvement or availability of established improvement program in the company was another selection criterion. The firms were solicited to participation by email, calling or personal visit when appropriate.

To ensure reliability and comprehensiveness of the survey instrument, we consulted 2 faculty members, 2 senior consultants as well as 4 continuous improvement managers. Upon receiving manifold feedback, the instrument was modified prior to large-scale study. As a final step in preparation of the survey, we conducted a pilot study on twenty-two companies to confirm the feasibility of selected approach and instrument (Dillman, Smyth, \& Christian, 2014). A custom web-survey that generated and sent a unique link to the respondents was used for data collection. Customized online survey ensured security and privacy of the research participants (Dillman et al., 2014). To ensure reliability of the results and to avoid bias, we aimed at collecting multiple responses from top managers, team leaders and front-line employees at the participating (Woodside, 2016). We applied a pessimistic approach to aggregate data at the company level through subtraction of the minimum values from the responses in each case (Hastie, Tibshirani, \& Friedman, 2001). The final response rate 
Tab. 1: Demographics of participating companies

\begin{tabular}{l|c|c|c|c}
\multicolumn{1}{c|}{ Services branch } & $\begin{array}{c}\text { Czech } \\
\text { Republic }\end{array}$ & $\begin{array}{c}\text { Slovak } \\
\text { Republic }\end{array}$ & Hungary & Poland \\
\hline Finance & 17 & 6 & 12 & 14 \\
\hline Accounting & 16 & 5 & 15 & 15 \\
\hline Human Resources & 12 & 5 & 9 & 14 \\
\hline Logistics & 10 & 3 & 7 & 17 \\
\hline Information Technology & 15 & 5 & 10 & 15 \\
\hline Customer Support & 18 & 5 & 19 & 13 \\
\hline Procurement & 9 & 3 & 7 & 8 \\
\hline Total & 97 & 32 & 79 & 96 \\
\hline \% of basic sample & $54 \%$ & $53 \%$ & $72 \%$ & $12 \%$ \\
\hline
\end{tabular}

Source: own based on ABSL CZ (2016), HIPA (2015), PITA (2015), SARIO (2015)

accounted for $62 \%$. The sample consists of 304 companies that provide a wide spectrum of services: finance, accounting, human resources, logistics, information technology (including systems support), customer support and procurement. Since Visegrad group experienced economic transition and increased participation in the international services trade (OECD, 2015), we expect a pronounced variability in the $\mathrm{Cl}$ performance and practices (Schroeder \& Flynn, 2001; Zeng et al., 2013). Tab. 1 provides an overview of the participating companies.

\section{Results}

To clearly ascertain the effect of mediators on the outcome variable (Customer Satisfaction), the mediating variables and their respective best responses were further analyzed. Over $58.1 \%$ of the respondents report to have an effective recognition and reward systems, $67.3 \%$ have a corporate culture oriented on quality, $64.9 \%$ have commitment of management to the improvement initiative, $30.6 \%$ deliver proper training and learning for project participants and $87 \%$ set clear goals for improvement of program.

\subsection{Reliability Test}

The reliability analysis was carried out using Cronbach Alpha to identify the relationship between items and the level of internal consistency. Cronbach's coefficient $\alpha$ values of more than 0.7 were considered to be consistent and reliable. The higher the value of Cronbach's coefficient $\alpha$ or the closer alpha is to 1.0 , the higher the reliability of the measurement item. As indicated in Tab. 2, the Cronbach's alpha value of the standardization construct was 0.898 and 0.798 for the mediators. The values recorded for all the constructs signify a very strong internal consistency measurement components and the reliability of further analysis guaranteed.

\subsection{Exploratory Factor Analysis}

Exploratory Factor Analysis (EFA) was performed on the data to condense and summarize data

\section{Tab. 2: Reliability statistics}

\begin{tabular}{l|c|c|c}
\multicolumn{1}{c|}{ Construct } & $\begin{array}{c}\text { Cronbach's Alpha } \\
(\boldsymbol{\alpha})\end{array}$ & $\begin{array}{c}\text { Cronbach's Alpha Based } \\
\text { on Standardized Items }\end{array}$ & N of Items \\
\hline Standardization & 0.898 & 0.900 & 4 \\
\hline Mediators & 0.798 & 0.899 & 5 \\
\hline
\end{tabular}


into smaller components. The use of EFA further revealed the convergence level of items. The EFA assisted in hypothesizing concepts in the initial analysis. According to Hair, Tatham, Anderson, and Black (1998), factor loadings greater than 0.30 are significant, 0.40 are important while 0.50 or more are very significant. Also by rule of thumb, factor loadings of 0.50 or greater are considered very significant to be used for further analysis. This paper adopted factor loadings of 0.50 or greater to be very significant and further applied the 0.50 factor loading in the Path analysis for the hypotheses. Prior to the factor analysis, an apriori analysis based on the Principal Component Analysis (PCA) was carried out to determine the suitability of factor analysis on the data using the Kaiser-MeyerOlkin (KMO) Measure of Sampling Adequacy and the Bartlett's Test of Sphericity. As indicated in Tab. 3, the Bartlett's Test of Sphericity is statistically significant at a $\mathrm{P}=0.00$, a KMO of 0.778 and a correlation matrix producing correlations of 0.30 or above between variables.
The PCA was adapted to produce the eigenvalues in the factor loadings table. Eigenvalues of at least 1 were highly retained. However, other initial values closer to one were also considered, since the measurement variables are few. Three measurement items in standardization account for $90.881 \%$ of total variance and two mediating variables accounted for $70.33 \%$ of total variance as indicated in Tab. 3. For convergent and discriminant validity, the constructs/dimensions satisfied prior requirements with factor loadings greater than 0.50 .

\subsection{Confirmatory Factor Analysis Using Structural Equation Models (SEM)}

To respond to the hypothesis, first the direct impact of standardization on CS was assessed. Then mediation variables such as rewards, quality-oriented culture, management commitment, training and goal setting were introduced to ascertain the impact of such mediators on the outcomes with the effect

\section{Tab. 3: Total variance explained}

\begin{tabular}{|c|c|c|c|c|c|c|}
\hline \multirow{2}{*}{ Component } & \multicolumn{3}{|c|}{ Initial Eigenvalues } & \multicolumn{3}{|c|}{$\begin{array}{c}\text { Extraction Sums of Squared } \\
\text { Loadings }\end{array}$} \\
\hline & Total & $\begin{array}{c}\% \\
\text { of Variance } \\
\end{array}$ & $\begin{array}{c}\text { Cumulative } \\
\%\end{array}$ & Total & $\begin{array}{c}\% \\
\text { of Variance } \\
\end{array}$ & $\begin{array}{c}\text { Cumulative } \\
\%\end{array}$ \\
\hline \multicolumn{7}{|l|}{ Standardization } \\
\hline A1 & 1.809 & 47.324 & 57.324 & 1.809 & 47.324 & 47.324 \\
\hline $\mathrm{A} 2$ & 1.454 & 22.003 & 69.327 & 1.454 & 22.003 & 69.327 \\
\hline A3 & 1.001 & 21.554 & 90.881 & 1.001 & 21.554 & 90.881 \\
\hline A4 & .866 & 9.119 & 100.00 & & & \\
\hline \multicolumn{7}{|l|}{ Mediators } \\
\hline $\mathrm{C} 1$ & 1.56 & 44.18 & 44.18 & 1.56 & 44.18 & 44.18 \\
\hline $\mathrm{C} 2$ & 1.03 & 26.15 & 70.33 & 1.03 & 26.15 & 70.33 \\
\hline C3 & .75 & 15.75 & 86.08 & & & \\
\hline $\mathrm{C} 4$ & .70 & 13.92 & 100.00 & & & \\
\hline \multicolumn{7}{|c|}{ KMO and Bartlett's Test } \\
\hline \multicolumn{6}{|c|}{ Kaiser-Meyer-Olkin Measure of Sampling Adequacy } & .778 \\
\hline \multirow{3}{*}{\multicolumn{4}{|c|}{ Bartlett's Test of Sphericity }} & \multicolumn{2}{|c|}{ Approx. Chi-Square } & $2,278.132$ \\
\hline & & & & \multicolumn{2}{|l|}{ df. } & 92 \\
\hline & & & & \multicolumn{2}{|l|}{ Sig. } & .000 \\
\hline
\end{tabular}




\begin{tabular}{l|c|c|c|c}
\multirow{2}{*}{\multicolumn{1}{c|}{ Latent Variable }} & \multicolumn{4}{|c}{ Standardization } \\
\cline { 2 - 5 } & A1 & A2 & A3 & A4 \\
\hline Customer Satisfaction & $0.459^{* *}$ & $0.384^{* *}$ & $0.223^{*}$ & -0.411 \\
\hline P-Value & 0.000 & 0.003 & 0.000 & 0.103 \\
\hline
\end{tabular}

Source: own

Note: **, * Correlation is significant at 0.01 and 0.05 levels (two tailed), respectively.

\section{Tab. 5: Quality criteria}

\begin{tabular}{l|c|c|c|c|c|c}
$\begin{array}{c}\text { Latent } \\
\text { Variable }\end{array}$ & Symbols & $\begin{array}{c}\text { Bootstrapped } \\
\text { T-Value } \\
\text { (loadings) }\end{array}$ & Loadings & $\begin{array}{c}\text { Composite } \\
\text { Reliability }\end{array}$ & $\begin{array}{c}\text { Cronbach's } \\
\text { Alpha }\end{array}$ & AVE \\
\hline \multirow{4}{*}{ Standardization } & A1 & 3.657 & 0.792 & 0.850 & 0.750 & 0.587 \\
\cline { 2 - 7 } & A2 & 3.302 & 0.696 & & & \\
\cline { 2 - 7 } & A3 & 4.500 & 0.822 & & & \\
\cline { 2 - 7 } & A4 & 3.046 & 0.676 & & & \\
\hline
\end{tabular}

Source: own

on the Latent Variable (see Appendix A). Correlations were determined to analyze the strength of relationship between the variables. From Tab. 4, three measurement items of standardization significantly relate to the outcome variable of customer satisfaction.

The model generated to respond to the hypotheses was evaluated to validate the internal consistency reliability, convergent validity and discriminant validity. The Average Variance Extracted (AVE) was used to validate the convergent validity of the latent variable in the model. It can be observed in Tab. 5 that all the measurement items are above the threshold of 0.5 as by rule of thumb. The square root of AVE, using the Fornell-Lacker Criterion Discriminant Validity Test, has high diagonal results of 0.722 . This confirms the discriminant validity of the model.

\subsection{Testing Impact of Mediators on Standardization-Customer Satisfaction Relationship}

Customer satisfaction is dependent on a lot of variables. Companies may misappropriate certain conditions for customer satisfaction without carefully aligning variables of influence. This paper further assessed the parameters closely associated with customer satisfaction by developing six hypotheses. The model in Fig. 1, and the results deplored in Tab. 6 present the pictorial findings. Using the standardization latent variables with mediators applied, the model in Fig. 1 incorporates Customer satisfaction as the output variable. The model is highly fit to be analyzed and deployed in practical settings. A careful analyses of the fit indices in Tab. 6 indicate that chi-square is not significant at a test statistic of 0.05 , RMSEA $<0.05$ and CFI is 0.971 . From Tab. 6 and Fig. 2, $\mathrm{H} 3$ and $\mathrm{H} 6$ are the hypotheses not supported in the analysis. The greater the level of standardization in a company, the higher the positive impact on CS. This result is supported by a $99.974 \%$ of accuracy, 0.000 P-value and a T-statistic of above 2.

For CS to be enhanced, rewards and recognition for employees involved in standardization must be in place, which is confirmed by the result of the second hypothesis with a $p$-value of 0.011 . The other measurement indices favor the conclusion drawn for hypothesis 2 . The commitment of management 


\section{Marketing and Trade}

\section{Fig. 1: Model with mediators for customer satisfaction}

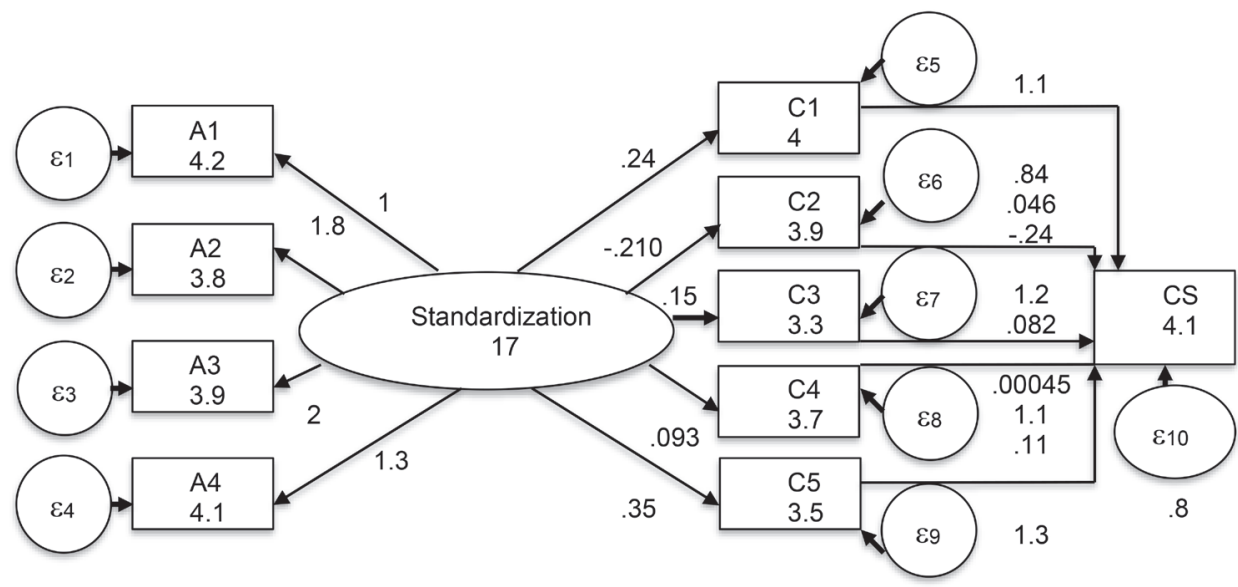

Source: own

\section{Tab. 6: Hypotheses evaluation and fit indices for Customer Satisfaction (CS)}

\begin{tabular}{l|l|c|c|c|c|l} 
Hypothesis & \multicolumn{1}{|c|}{ Model Path } & Coefficient & P-Value & S.E. & T-Statistic & Outcome \\
\hline $\mathrm{H} 1$ & Standardization $\rightarrow \mathrm{CS}$ & 0.740 & 0.000 & 0.026 & 3.913 & Supported \\
\hline $\mathrm{H} 2$ & $\begin{array}{l}\text { Standardization } \rightarrow \\
\text { Rewards } \rightarrow \text { CS }\end{array}$ & 0.243 & 0.011 & 0.000 & 2.442 & Supported \\
\hline $\mathrm{H} 3$ & $\begin{array}{l}\text { Standardization } \rightarrow \\
\text { Quality culture } \rightarrow \mathrm{CS}\end{array}$ & -0.021 & 0.881 & 0.143 & 2.113 & Not Supported \\
\hline $\mathrm{H} 4$ & $\begin{array}{l}\text { Standardization } \\
\rightarrow \text { management } \\
\text { commitment } \rightarrow \mathrm{CS}\end{array}$ & 0.153 & 0.001 & 0.016 & 3.318 & Supported \\
\hline $\mathrm{H} 5$ & $\begin{array}{l}\text { Standardization } \rightarrow \\
\text { employee training } \rightarrow \mathrm{CS}\end{array}$ & 0.093 & 0.021 & 0.052 & 3.854 & Supported \\
\hline $\mathrm{H} 6$ & $\begin{array}{l}\text { Standardization } \rightarrow \text { Goal } \\
\text { setting and Project } \\
\text { Management } \rightarrow \mathrm{CS}\end{array}$ & 0.347 & 0.057 & 0.033 & 3.616 & Not Supported \\
\hline
\end{tabular}

Chi2 $=733.726$

$\mathrm{P}>\mathrm{chi} 2=0.058$

$\mathrm{R}^{2}=0.980$

RMSEA $=0.034$

$\mathrm{df}=304$

$\mathrm{CFI}=0.971$ 
in all facets of the company's activities has a positive impact on the relationship between standardization and $\mathrm{CS}$ as confirmed in $\mathrm{H} 4$. With a p-value of 0.021 , a $5 \%$ standard error and a T-statistic of above 2, $\mathrm{H} 5$ is confirmed that employee training for standardization influences CS.

\subsection{Comparison of the Factors Impacting Standardization across Visegrad Countries}

To assess the differences between the countries, the same theoretical models were applied to the country-level data. In analyzing individual focus areas (mediating variables) influencing the standardization process for CS among participating countries (V4 group), the results indicate that the influence of employee rewards \& recognition in standardization process for CS is more prominent in Hungary with a P-value of $0.020,4 \%$ standard error and a T-statistic of above 2. The Slovak Republic however incorporates corporate culture as a mediating variable more in the standardization process for CS with a p-value of 0.045 . The Czech Republic leads in using management commitment as a mediating variable in standardization for CS while Poland is much more focused on employee training \& development in the standardization process for CS. For the mediating variable of goal setting \& project management in the standardization process, results indicate that all the V4 countries do not support the hypothesis. Results indicate P-values of $0.051,0.055,0.056$ and 0.060 for Hungary, the Czech Republic, Slovak Republic and Poland respectively signifying non-supporting of goal setting \& project management in mediating standardization for CS. Standardization has however been supported as a backbone for CS with variety of focus catalyst by respective Countries.

\section{Discussion and Conclusions}

The proposed study contributes to the scarce field of standardization application to the service processes. The quality of service operations and customer satisfaction depends on the customer perception; thus, organizations needs to compromise between excessive customization and standardization to sustain their competitiveness. Based on the analysis of 304 service companies, we evaluated the effect of standardization on customer satisfaction. Our research confirms that standardization of processes leads to the improved customer satisfaction, in line with the seminal works on operations management by Deming (1993), Imai (1986) and Liker and Morgan (2006). Further research is needed to investigate whether this claim will remain true with the growing level of standardization, since Afflerbach, Bolsinger and Röglinger (2016) suggest to exercise caution in terms of intensity and level of standardization: it may be reasonable to standardize processes only to a certain level to avoid reduction of customer satisfaction.

The study also contributes to the scant research on the factors impacting the standardization-customer satisfaction relationship. In our study we provide an alternative view on the factors impacting effectiveness of standardization and further explore differences in the factors affecting standardization in the Visegard countries. We consider standardization an integral part of continuous improvement and study the impact of the factors that are proven to foster effectiveness of continuous improvement on process standardization. Due to the high fit of developed model, the research findings can be deployed in practical settings and provide interesting insights for further scholarly work. The findings can serve as a guiding tool for standardization of the processes in the domains of investment prioritization and strategy development.

Our analysis reveals that companies, embarking on standardization journey, should focus their investment and organization efforts on appropriate rewards and recognition system, training of employees and management commitment to further reinforce the positive impact of standardization on customer satisfaction. Appropriate rewards and recognition system stimulates employees to identify and implement standardization opportunities (Habtoor, 2016; Yang et al., 2014). Nevertheless, employees should receive an appropriate training to have the right level of skills to identify standardization opportunities. The specific training on improvement methods received little attention in the research, and the given study highlights importance of the specific training on improvement methods to the effectiveness of standardization. Interestingly, Polish companies demonstrate higher focus on training compared to other countries. 
Researchers have previously demonstrated importance of management commitment to improvement efforts (Bortolotti et al., 2015; Habtoor, 2016; Powell, 1995), and our analysis further confirms the importance of management commitment to drive standardization efforts forward. The analysis reveals that the triad of training, rewards and management commitment are cardinal to improvement of customer satisfaction through process standardization in the service organizations. However, further analysis demonstrated certain regional differences across countries, resulting in the different role played by the selected factors in standardization.

Surprisingly, quality-oriented culture and project management do not play a significant role in the effectiveness of standardization according to our analysis in the general dataset. However, when exploring country differences, we identified that Czech companies have a comparably higher focus on management commitment, while Slovak - on corporate culture. Previous research emphasized that quality-oriented culture plays foundational role for the improvement efforts (Calvo-Mora et al., 2013; Habtoor, 2016), however, our research demonstrates that organizations can achieve improvement of customer satisfaction through standardization of the processes without establishing sophisticated qualityoriented culture. We further suggest that the case of Czech companies provides an interesting case for further exploration of the corporate culture impact on standardization. Researchers provide extensive evidence of the importance of appropriate goal setting and project management for the improvement initiatives (Anand et al., 2009; Choo et al., 2007; Jääskeläinen et al., 2014); however, based on the conducted analysis, it can be suggested that standardization does not require a thorough goal setting. It can be hypothesized that the reason behind this finding lies in the rather "technical" nature of the standardization: the existing activities are unified to reduce complexity to achieve maximum utilization of the established processes, and does not involve design of the novel operations. Thus, it can be suggested, that effectiveness of process standardization is not affected by the changes of organizational priorities, and remains an effective tool for improvement of customer satisfaction even in the unstable periods of the company existence. Further research is needed to confirm this claim, and to investigate the role of standardization for the companies in the time of transformational change.

We would like to thank the Internal Grant Agency of Tomas Bata University in Zlin (grant number IGA/Fame/2017/008, IGA FaME/2016/007 and VaV-IP-RO/2016/03) as well as the Visegrad Fund (grant number 51700045) for financial support. We would also like to express our gratitude to Nikita Nikitin from WebKr Gmbh for the technical support and help with the online survey.

\section{References}

ABSL. (2016). Business Services Sector in Poland. Retrieved December 15, 2016, from http://absl.pl/wp-content/uploads/2016/09/ Raport_ABSL_2016_EN.pdf.

Afflerbach, P., Bolsinger, M., \& Röglinger, M. (2016). An economic decision model for determining the appropriate level of business process standardization. Business Research, 9(2), 335-375. https://doi.org/10.1007/s40685016-0035-6.

Anand, G., Chhajed, D., \& Delfin, L. (2012). Job autonomy, trust in leadership, and continuous improvement: An empirical study in health care. Operations Management Research, 5(3-4), 70-80. https://doi.org/10.1007/s12063012-0068-8.

Anand, G., Ward, P. T., Tatikonda, M. V., \& Schilling, D. A. (2009). Dynamic capabilities through continuous improvement infrastructure. Journal of Operations Management, 27(6), 444461. https://doi.org/10.1016/j.jom.2009.02.002.

Anderson, E. W., Fornell, C., \& Rust, R. T. (1997). Customer Satisfaction, Productivity, and Profitability: Differences Between Goods and Services. Marketing Science, 16(2), 129145. https://doi.org/10.1287/mksc.16.2.129.

Anderson, J. C., Rungtusanatham, M., Schroeder, R. G., \& Devaraj, S. (1995). A Path Analytic Model of a Theory of Quality Management Underlying the Deming Management Method: Preliminary Empirical Findings. Decision Sciences, 26(5), 637-658. https://doi. org/10.1111/j.1540-5915.1995.tb01444.x.

Babbar, S. (1992). A Dynamic Model for Continuous Improvement in the Management of Service Quality. International Journal of Operations \& Production 
Management, 12(2), 38-48. https://doi. org/10.1108/01443579210009041.

Berger, A. (1997). Continuous improvement and kaizen: standardization and organizational designs. Integrated Manufacturing Systems, 8(2), 110-117. https://doi.org/10.1108/09576069710165792.

Bessant, J., \& Francis, D. (1999). Developing strategic continuous improvement capability. International Journal of Operations \& Production Management, 19(11), 1106-1119. https://doi.org/10.1108/01443579910291032.

Boon Sin, A., Zailani, S., Iranmanesh, M., \& Ramayah, T. (2015). Structural equation modelling on knowledge creation in Six Sigma DMAIC project and its impact on organizational performance. International Journal of Production Economics, 168, 105-117. https://doi.org/10.1016/j.ijpe.2015.06.007.

Bortolotti, T., Boscari, S., \& Danese, P. (2015). Successful lean implementation: Organizational culture and soft lean practices. International Journal of Production Economics, 160, 182201. https://doi.org/10.1016/j.ijpe.2014.10.013.

Calvo-Mora, A., Picón, A., Ruiz, C., \& Cauzo, L. (2013). Soft-hard TQM factors and key business results. International Journal of Operations \& Production Management, 34(1), 115-143. https://doi.org/10.1108/IJOPM-09-2012-0355.

Carlborg, P., Kindström, D., \& Kowalkowski, C. (2013). A lean approach for service productivity improvements: Synergy or oxymoron? Managing Service Quality: An International Journal, 23(4), 291-304. https:// doi.org/10.1108/MSQ-04-2013-0052.

Chakravorty, S. S. (2009). Six Sigma programs: An implementation model. International Journal of Production Economics, 119(1), 1-16. https://doi.org/10.1016/j.ijpe.2009.01.003.

Chiang, C. F., \& Wu, K. P. (2014). The influences of internal service quality and job standardization on job satisfaction with supports as mediators: Flight attendants at branch workplace. International Journal of Human Resource Management, 25(19), 2644-2666. https://doi.org/10.1080/09585192.2014.884616.

Choo, A. S., Linderman, K. W., \& Schroeder, R. G. (2007). Method and context perspectives on learning and knowledge creation in quality management. Journal of Operations Management, 25(4), 918-931. https://doi. org/10.1016/j.jom.2006.08.002.

Chromjaková, F. (2016). The Key Principles of Process Manager Motivation in Production and Administration Processes in an Industrial Enterprise. Journal of Competitiveness, 8(1), 95-110. https://doi.org/10.7441/joc.2016.01.07.

Crosby, P. B. (1979). Quality is Free: The Art of Making Quality Certain. New York, NY: McGraw-Hill.

Czechlnvest. (2015). Sector databases. Retrieved May 9, 2016, from https://suppliers. czechinvest.org/Aplikace/suppliers_ext.nsf/ index.xsp.

Davenport, T. H. (2005). The Coming Commoditization of Processes. Harvard Business Review, 83(6), 100-108.

Deming, W. E. (1993). The New Economics for Industry, Government, Education (2nd ed.). Cambridge, MA: Mit University Press Group Ltd.

Detert, J. R., Schroeder, R. G., \& Mauriel, J. J. (2000). A framework for linking culture and improvement initiatives in organizations. Academy of Management Review, 25(4), 850-863. https://doi.org/10.5465/AMR.2000.3707740.

Dillman, D. A., Smyth, J. D., \& Christian, L. M. (2014). Internet, Phone, Mail, and MixedMode Surveys. The Tailored Design Method (4th ed.). Hoboken, NJ: Wiley.

Ding, Y., \& Keh, H. T. (2016). A reexamination of service standardization versus customization from the consumer's perspective. Journal of Services Marketing, 30(1), 16-28. https://doi.org/10.1108/JSM-02-2015-0088.

Dow, D., Samson, D., \& Ford, S. (1999). Exploding the Myth: Do All Quality Management Practices Contribute to Superior Quality Performance? Production and Operations Management, 8(1), 1-27. https:// doi.org/10.1111/j.1937-5956.1999.tb00058.x.

Duncan, R. G. (1972). Characteristics of organizational environments and perceived environmental uncertainty. Administrative Science Quarterly, 17(2), 313-327. https://doi. org/10.2307/2392145.

Edmondson, A. C., \& McManus, S. E. (2007). Methological fit in management field research. Academy of Management Review, 32(4), 1155-1179. https://doi.org/10.5465/ AMR.2007.26586086.

Galeazzo, A., Furlan, A., \& Vinelli, A. (2016). The organizational infrastructure of continuous improvement - an empirical analysis. Operations Management Research, 10(1-2), 33-46. https:// doi.org/10.1007/s12063-016-0112-1.

George, M. L. (2003). Lean Six Sigma for Service. New York, NY: McGraw-Hill. https:// doi.org/10.1036/0071436359. 
Gilson, L. L., Mathieu, J. E., Shalley, C. E., \& Ruddy, T. M. (2005). Creativity and Standardization: Complementary or Conflicting Drivers of Team Effectiveness? The Academy of Management Journal, 48(3), 521-531. https://doi.org/10.5465/AMJ.2005.17407916.

Gonzalez, R. V. D., \& Martins, M. F. (2016). Capability for continuous improvement. TQM Journal, 28(2), 250-274. https://doi.org/10.1108/ TQM-07-2014-0059.

Habtoor, N. (2016). Influence of human factors on organisational performance: quality improvement practices as a mediator variable. International Journal of Productivity and Performance Management, 65(4), 460-484. https://doi.org/10.1108/IJPPM-02-2014-0016.

Haikonen, A., Savolainen, T., \& Järvinen, P. (2004). Exploring Six Sigma and Cl capability development: preliminary case study findings on management role. Journal of Manufacturing Technology Management, 15(4), 369-378. https://doi.org/10.1108/17410380410535071.

Hair, J. F., Tatham, R. L., Anderson, R. E., \& Black, W. (1998). Multivariate Data Analysis with Readings. Englewood Cliffs, NJ: Prentice-Hall.

Hart, C. W. L. (1995). Mass customization: conceptual underpinnings, opportunities and limits. International Journal of Service Industry Management, 6(2), 36-45. https://doi. org/10.1108/09564239510084932.

Hastie, T., Tibshirani, R., \& Friedman, J. (2001). The Elements of Statistical Learning. New York, NY: Springer. https://doi. org/10.1007/978-0-387-21606-5.

HIPA. (2015). Shared Service Centers. Retrieved November 14, 2016, from https://hipa.hu/ssc.

Hsiao, Y. H., Chen, L. F., Chang, C. C., \& Chiu, F. H. (2016). Configurational path to customer satisfaction and stickiness for a restaurant chain using fuzzy set qualitative comparative analysis. Journal of Business Research, 69(8), 2939-2949. https://doi. org/10.1016/j.jbusres.2015.12.063.

Hsieh, Y.-M., \& Hsieh, A.-T. (2001). Enhancement of service quality with job standardisation. The Service Industries Journal, 21(3), 147-166. https://doi. org/10.1080/714005029.

Imai, M. (1986). Kaizen. New York: McGrawHill Education.

Jääskeläinen, A., Laihonen, $H_{\text {., }}$ \& Lönnqvist, A. (2014). Distinctive features of service performance measurement. International Journal of Operations \& Production
Management, 34(12), 1466-1486. https://doi. org/10.1108/IJOPM-02-2013-0067.

Jayanth, J., \& Xu, K. (2016). Determinants of Quality and Efficiency Performance in Service Operations. International Journal of Operations \& Production Management, 36(3), 265-285. https://doi.org/10.1108/IJOPM-03-2014-0122.

Juran, J. M., \& Gryna, F. M. (1988). Juran's Quality Control Handbook (4th ed.). New York, NY: McGraw-Hill.

Kaye, M., \& Anderson, R. (1999). Continuous improvement: the ten essential criteria. International Journal of Quality \& Reliability Management, 16(5), 485-509. https://doi.org/10.1108/02656719910249801.

Kaynak, H. (2003). The relationship between total quality management practices and their effects on firm performance. Journal of Operations Management, 21(4), 405-435. https://doi.org/10.1016/S0272-6963(03)00004-4.

Kim, D.-Y., Kumar, V., \& Kumar, U. (2012). Relationship between quality management practices and innovation. Journal of Operations Management, 30(4), 295-315. https://doi. org/10.1016/j.jom.2012.02.003.

Laux, C., Johnson, M., \& Cada, P. (2015). Project barriers to Green Belts through critical success factors. International Journal of Lean Six Sigma, 6(2), 138-160. https://doi. org/10.1108/IJLSS-02-2014-0006.

Levitt, T. (1976). Industrialization of Services. Harvard Business Review, 54(5), 63-74.

Liker, J. K. (2004). The Toyota Way - 14 Management Principles from the World's Greatest Manufacturer. New York: McGraw-Hill.

Liker, J. K., \& Morgan, J. M. (2006). The Toyota Way in Services: The Case of Lean Product Development. Academy of Management Perspectives, 20(2), 5-20. https:// doi.org/10.5465/AMP.2006.20591002.

Lillrank, P., Shani, A. B. (Rami), \& Lindberg, P. (2001). Continuous improvement: Exploring alternative organizational designs. Total Quality Management, 12(1), 41-55. https://doi. org/10.1080/09544120020010084.

Matson, E. L., \& Stauffer, L. A. (2009). Developing an assessment tool for two organizations using six sigma principles. Engineering Management Journal, 21(4), 7-15. https://doi.org/10.1080/10429247.2009.11431840.

Münstermann, B., Eckhardt, A., \& Weitzel, T. (2010). The performance impact of business process standardization. Business Process Management Journal, 16(1), 29-56. https://doi. org/10.1108/14637151011017930. 
Münstermann, B., von Stetten, A., Laumer, S., \& Eckhardt, A. (2010). The performance impact of business process standardization: HR case study insights. Management Research Review, 33(9), 924-939. https://doi. org/10.1108/01409171011070332.

Nair, A., Malhotra, M. K., \& Ahire, S. L. (2011). Toward a theory of managing context in Six Sigma process-improvement projects: An action research investigation. Journal of Operations Management, 29(5), 529-548. https://doi.org/10.1016/j.jom.2010.11.014.

Nakamura, S. (1993). The New Standardization: Keystone of Continuous Improvement in Manufacturing. Portland, OR: Productivity Press.

OECD. (2015). OECD National Accounts Statistics.

Oláh, J., Szolnok, Á., Nagy, G., Lengyel, P., \& Popp, J. (2017). The Impact of Lean Thinking on Workforce Motivation: A Success Factor at LEGO Manufacturing Ltd. Journal of Competitiveness, 9(2), 93-109. https://doi. org/10.7441/joc.2017.02.07.

Parasuraman, A., Zeithaml, V. A., \& Berry, L. L. (1998). SERVQUAL: A multiple item scale for measuring consumer perceptions of service quality. Journal of Retailing, 64(5), 21-40.

Peng, D. X., Schroeder, R. G., \& Shah, R. (2008). Linking routines to operations capabilities: A new perspective. Journal of Operations Management, 26(6), 730-748. https://doi.org/10.1016/j.jom.2007.11.001.

Piercy, N., \& Rich, N. (2009). Lean transformation in the pure service environment: the case of the call service centre. International Journal of Operations \& Production Management, 29(1), 54-76. https://doi. org/10.1108/01443570910925361.

PITA. (2015). Foreign Investors in Poland. Retrieved October 15, 2016, from http://www. paih.gov.pl/publications/foreign_investors_in_ poland.

Pollitt, D. (2013). Training drives continuous improvement at electronics business. Training \& Management Development Methods, 27(2), 333-337.

Pont, G. D., Furlan, A., \& Vinelli, A. (2009). Interrelationships among lean bundles and their effects on operational performance. Operations Management Research, 1(2), 150-158. https://doi.org/10.1007/s12063-008-0010-2.

Powell, T. C. (1995). Total Quality Management as competitive advantage: a review and empirical study. Strategic Management Journal, 16(1), 15-37. https://doi. org/10.1002/smj.4250160105.

Prajogo, D. I., \& Brown, A. (2006). Approaches to adopting quality in SMEs and the impact on quality management practices and performance. Total Quality Management \& Business Excellence, 17(5), 555-566. https:// doi.org/10.1080/14783360600588042.

Pyzdek, T., \& Keller, P. A. (2009). The Six Sigma Handbook - A Complete Guide for Green Belts, Black Belts, and Managers at All Levels (3rd ed.). New York, NY: McGraw-Hill.

Ritzer, G. (2011). The McDonaldization of Society (6th ed.). Thousand Oaks, CA: Pine Forge Press.

Romero, H. L., Dijkman, R. M., Grefen, P. W. P. J., \& Van Weele, A. J. (2015). Factors that Determine the Extent of Business Process Standardization and the Subsequent Effect on Business Performance. Business and Information Systems Engineering, 57(4), 261-270. https://doi.org/10.1007/s12599-015-0386-0.

Rust, R. T., \& Chung, T. S. (2006). Marketing Models of Service and Relationships. Marketing Science, 25(6), 560-580. https://doi. org/10.1287/mksc.1050.0139.

Rust, R. T., Jeffrey, I. J., Jianmin, J., \& Zahorik, A. (1999). What You Don't Know About Customer-Perceived Quality: The Role of Customer Expectation Distributions. Marketing Science, 18(1), 77-92. https://doi.org/10.1287/ mksc.18.1.77.

Sabella, A., Kashou, R., \& Omran, O. (2014). Quality management practices and their relationship to organizational performance. International Journal of Operations \& Production Management, 34(12), 1487-1505. https://doi. org/10.1108/IJOPM-04-2013-0210.

Samson, D., \& Terziovski, M. (1999). The relationship between total quality management practices and operational performance. Journal of Operations Management, 17(4), 393-409. https://doi.org/10.1016/s0272-6963(98)00046-1.

SARIO. (2015). Shared Service \& Business Process Outsourcing Centers in Slovakia Outsoucing Centers. Retrieved February 2, 2017, from http://www.sario.sk/sites/default/ files/data/sario-ssc-web-2016-july-update.pdf.

Schäfermeyer, M., Rosenkranz, C., \& Holten, R. (2012). The impact of business process complexity on business process standardization: An empirical study. Business and Information Systems Engineering, 4(5), 
261-270. https://doi.org/10.1007/s12599-0120224-6.

Schroeder, R. G., \& Flynn, B. (2001). High performance manufacturing: global perspectives. New York: Wiley.

Shah, R., \& Goldstein, S. M. (2006). Use of structural equation modeling in operations management research: Looking back and forward. Journal of Operations Management, 24(2), 148-169. https://doi.org/10.1016/j. jom.2005.05.001.

Shaw, D. R., Holland, C. P., Kawalek, P., Snowdon, B., \& Warboys, B. (2007). Elements of a business process management system: theory and practice. Business Process Management Journal, 13(1), 91-107. https://doi.org/10.1108/14637150710721140.

Silvestro, R., \& Lustrato, P. (2015). Exploring the "mid office" concept as an enabler of mass customization in services. International Journal of Operations \& Production Management, 35(6), 866-894. https://doi. org/10.1108/09574090910954864.

Simonson, I., \& Nowlis, S. M. (2000). The Role of Explanations and Need for Uniqueness in Consumer Decision Making: Unconventional Choices Based on Reasons. Journal of Consumer Research, 27(1), 49-68. https://doi. org/10.1086/314308.

Swartling, D., \& Olausson, D. (2011). Continuous improvement put into practice. International Journal of Quality and Service Sciences, 3(3), 337-351. https://doi. org/10.1108/17566691111182870.

Taubitz, M. (2014). The Error of Standardization and Its Impact on Safety. Professional Safety, 59(8), 49-50.

Taylor, A., Taylor, M., \& McSweeney, A. (2013). Towards greater understanding of success and survival of lean systems. International Journal of Production Research, 51(22), 6607-6630. https://doi.org/10.1080/002 07543.2013.825382.
Tronvoll, B., Brown, S. W., Gremler, D. D., \& Edvardsson, B. (2011). Paradigms in service research. Journal of Service Management, 22(5), 560-585. https://doi. org/10.1108/09564231111174951.

Tsironis, L. K., \& Psychogios, A. G. (2016). Road towards Lean Six Sigma in service industry: a multi-factor integrated framework. Business Process Management Journal, 22(4), 812-834. https://doi.org/10.1108/BPMJ-08-2015-0118.

Tyagi, R., \& Gupta, P. (2013). Gauging performance in the service industry. The Journal of Business Strategy, 34(3), 4-15. https://doi.org/http://dx.doi.org/10.1108/JBS10-2012-0059.

Ungan, M. C. (2006). Standardization through process documentation. Business Process Management Journal, 12(2), 135-148. https://doi.org/10.1108/14637150610657495.

Wang, G., Wang, J., Ma, X., \& Qiu, R. G. (2010). The effect of standardization and customization on service satisfaction. Journal of Service Science, 2, 1-23. https://doi. org/10.1007/s12927-010-0001-3.

Woodside, A. G. (2016). The good practices manifesto: Overcoming bad practices pervasive in current research in business. Journal of Business Research, 69(2), 365-381. https://doi. org/10.1016/j.jbusres.2015.09.008.

Wuellenweber, K., Koenig, W., Beimborn, D., \& Weitzel, T. (2009). The impact of process standardization on business process outsourcing success. In R. Hirschheim, A. Heinzl, \& J. Dibbern (Eds.), Information Systems Outsourcing (3rd ed.) (pp. 527-548). https://doi.org/10.1007/978-3-540-88851-2_23.

Yang, Y., Lee, P. K. C., \& Cheng, T. C. E. (2014). Continuous improvement competence, employee creativity, and new service development performance: A frontline employee perspective. International Journal of Production Economics, 171, 275-288. https://doi.org/10.1016/j.ijpe.2015.08.006. 
Zeng, J., Phan, C. A., \& Matsui, Y. (2013). Supply chain quality management practices and performance: An empirical study. Operations Management Research, 6(1-2), 19-31. https:// doi.org/10.1007/s12063-012-0074-x.

Zomerdijk, L. G., \& de Vries, J. (2007). Structuring front office and back office work in service delivery systems - An empirical study of three design decisions. International Journal of Operations \& Production Management, 27(1), 108-131. https://doi. org/10.1108/01443570710714565.
Ing. Oksana Koval, Ph.D. Tomas Bata University in Zlin

Faculty of Management and Economics Department of Industrial Engineering and Information Systems

Czech Republic koval@utb.cz

Ing. Stephen Nabareseh, Ph.D. Tomas Bata University in Zlin

Faculty of Management and Economics Department of Statistics and Quantitative Methods

Czech Republic nabareseh@utb.cz

prof. Ing. Felicita Chromjaková, Ph.D. Tomas Bata University in Zlin

Faculty of Management and Economics

Department of Industrial Engineering and Information Systems Czech Republic chromjakova@utb.cz 


\section{Appendix A: Measurement item for SEM models}

\begin{tabular}{|c|c|c|c|}
\hline $\begin{array}{l}\text { Measurement } \\
\text { Item }\end{array}$ & $\begin{array}{l}\text { Item } \\
\text { Code }\end{array}$ & Item Description & Supporting References \\
\hline \multicolumn{4}{|c|}{ Independent Variable } \\
\hline \multirow[t]{4}{*}{ Standardization } & $\mathrm{A} 1$ & $\begin{array}{l}\text { We usually develop standard } \\
\text { operating procedures for all } \\
\text { processes. }\end{array}$ & $\begin{array}{l}\text { Peng, Schroeder, \& Shah, 2008; } \\
\text { Pont et al., 2009; Taylor, Taylor, \& } \\
\text { McSweeney, 2013; Ungan, } 2006\end{array}$ \\
\hline & $\mathrm{A} 2$ & $\begin{array}{l}\text { We tend to standardize } \\
\text { processes between served } \\
\text { clients. }\end{array}$ & $\begin{array}{l}\text { Anand et al., 2009; Gonzalez \& } \\
\text { Martins, 2016; Liker \& Morgan, } 2006\end{array}$ \\
\hline & A3 & $\begin{array}{l}\text { We usually use Best Practices as } \\
\text { an example to follow and change } \\
\text { other processes accordingly. }\end{array}$ & $\begin{array}{l}\text { Chakravorty, 2009; Kaye \& Anderson, } \\
\text { 1999; Sabella et al., } 2014\end{array}$ \\
\hline & A4 & $\begin{array}{l}\text { We tend to standardize } \\
\text { processes between served } \\
\text { countries. }\end{array}$ & $\begin{array}{l}\text { Deming, 1993; Kim et al., 2012; Liker \& } \\
\text { Morgan, 2006; Powell, 1995; Swartling } \\
\text { \& Olausson, } 2011\end{array}$ \\
\hline \multicolumn{4}{|l|}{ Mediators } \\
\hline $\begin{array}{l}\text { Employee } \\
\text { Rewards and } \\
\text { Recognition }\end{array}$ & C1 & $\begin{array}{l}\text { Our company has established an } \\
\text { effective recognition and reward } \\
\text { system to stimulate employee } \\
\text { participation in Continuous } \\
\text { Improvement. }\end{array}$ & $\begin{array}{l}\text { Bessant \& Francis, 1999; Deming, } \\
\text { 1993; Dow et al., 1999; Nair, Malhotra, } \\
\text { \& Ahire, 2011; Yang et al., } 2014\end{array}$ \\
\hline Quality Culture & $\mathrm{C} 2$ & $\begin{array}{l}\text { Our company has a strong } \\
\text { corporate culture oriented on } \\
\text { quality and supports associated } \\
\text { cultural changes. }\end{array}$ & $\begin{array}{l}\text { Bortolotti et al., 2015; Calvo-Mora et } \\
\text { al., 2013; Dow et al., 1999; Gonzalez \& } \\
\text { Martins, 2016; Habtoor, 2016; Jayanth } \\
\text { \& Xu, 2016; Sabella et al., } 2014 \\
\end{array}$ \\
\hline $\begin{array}{l}\text { Management } \\
\text { Commitment }\end{array}$ & C3 & $\begin{array}{l}\text { Management } \\
\text { of the company shows a strong } \\
\text { commitment to } \mathrm{Cl} \text { through } \\
\text { regular communication about } \mathrm{Cl} \text {, } \\
\text { participation in the improvement } \\
\text { events and visible support } \\
\text { to the } \mathrm{Cl} \text { program. }\end{array}$ & $\begin{array}{l}\text { Anand, Chhajed, \& Delfin, 2012; } \\
\text { Bortolotti et al., 2015; Calvo-Mora et al., } \\
\text { 2013; Habtoor, 2016; Nair et al., 2011; } \\
\text { Powell, 1995; Samson \& Terziovski, } \\
1999\end{array}$ \\
\hline $\begin{array}{l}\text { Training and } \\
\text { development }\end{array}$ & $\mathrm{C} 4$ & $\begin{array}{l}\text { Our company ensures that } \\
\text { employees, participating in } \mathrm{Cl} \\
\text { projects, received proper training } \\
\text { and learning opportunities. }\end{array}$ & $\begin{array}{l}\text { Bortolotti et al., 2015; Dow et al., 1999; } \\
\text { Habtoor, 2016; Jayanth \& Xu, 2016; } \\
\text { Laux, Johnson, \& Cada, 2015; Pont et } \\
\text { al., 2009; Yang et al., 2014; Zeng et } \\
\text { al., 2013 }\end{array}$ \\
\hline $\begin{array}{l}\text { Goal Setting } \\
\text { and Project } \\
\text { Management }\end{array}$ & C5 & $\begin{array}{l}\text { Our company sets goals and } \\
\text { improvement projects that focus } \\
\text { on customer needs. }\end{array}$ & $\begin{array}{l}\text { Anand et al., 2009; Calvo-Mora et al., } \\
\text { 2013; Galeazzo et al., 2016; Kaynak, } \\
\text { 2003; Sabella et al., } 2014\end{array}$ \\
\hline \multicolumn{4}{|c|}{ Outcome Variable } \\
\hline $\begin{array}{l}\text { Customer } \\
\text { Satisfaction }\end{array}$ & D2 & $\begin{array}{l}\text { We have improved customer } \\
\text { satisfaction through continuous } \\
\text { improvement projects in our } \\
\text { company. }\end{array}$ & $\begin{array}{l}\text { Anderson et al., 1995; Deming, 1993; } \\
\text { Imai, 1986; Jayanth \& Xu, 2016; Piercy } \\
\text { \& Rich, } 2009\end{array}$ \\
\hline
\end{tabular}




\section{Abstract}

\section{STANDARDIZATION IN SERVICES: ASSESSING THE IMPACT ON CUSTOMER SATISFACTION}

\section{Oksana Koval, Stephen Nabareseh, Felicita Chromjaková}

To achieve high competitiveness, the companies need to satisfy varying customer needs. The changing nature of customer preferences leads to the increased complexity of the processes in service companies. In order to deliver the services of the high quality at the accepted costs, the companies resort to the process standardization. However, excessive process standardization may lead to company's inability to cater to the different customer needs, and hinder firm competitiveness over time. The goal of the present study, thus, is to evaluate the impact of standardization on customer satisfaction, and identify factors that can further foster this relationship. We identify the factors that impact the standardization-customer satisfaction relationship through exploratory and confirmatory factor analysis, and then perform a structural equation model linking standardization to customer satisfaction in the system of multiple mediating factors. The analysis of 304 firms reveals the positive impact of standardization on customer satisfaction. We further evaluate the effect of employee rewards and recognition system, quality-oriented culture, management commitment, training and development as well as goal setting and project management on standardizationcustomer satisfaction relationship. The analysis reveals the triad of the factors that are cardinal to improvement of customer satisfaction through standardization: training on improvement methods, rewards and recognition of employees to stimulate their participation in improvement initiatives, as well as management commitment. Further analysis reveals certain regional differences in the prevailing factors contributing to standardization across studied countries. The study contributes to the scarce field of knowledge of standardization application in services domain as well as provide directions for the further scholarly work in the field of process improvement and standardization as well as guidelines for the practitioners conducting process improvement in their organizations.

Key Words: Standardization, customer satisfaction, continuous improvement, Structural Equation Modeling (SEM).

JEL Classification: L8, L12, O33.

DOI: 10.15240/tul/001/2019-3-012 